\title{
Visual communication and learning from COVID-19 to advance preparedness for pandemics
}

\author{
José de la Fuente ${ }^{1,2^{*}}$ (1) José Bedia ${ }^{3}$, Christian Gortázar ${ }^{1}$ (1) \\ ${ }^{1}$ SaBio, Instituto de Investigación en Recursos Cinegéticos IREC-CSIC-UCLM-JCCM, 13005 Ciudad Real, Spain \\ ${ }^{2}$ Department of Veterinary Pathobiology, Center for Veterinary Health Sciences, Oklahoma State University, Stillwater, OK \\ 74078, USA \\ ${ }^{3}$ Bedia Studio, Miami, FL 33155, USA
}

*Correspondence: José de la Fuente, SaBio, Instituto de Investigación en Recursos Cinegéticos IREC-CSIC-UCLM-JCCM, Ronda de Toledo s/n, 13005 Ciudad Real, Spain. jose_delafuente@yahoo.com

Academic Editor: Emmanuel Lagarde, Bordeaux Population Health Research Center-U1219, Inserm, France

Received: June 22, 2020 Accepted: June 29, 2020 Published: August 31, 2020

Cite this article: de la Fuente J, Bedia J, Gortázar C. Visual communication and learning from COVID-19 to advance preparedness for pandemics. Explor Med. 2020;1:244-7. https://doi.org/10.37349/emed.2020.00016

\begin{abstract}
The currently ongoing coronavirus disease 19 (COVID-19) pandemic has affected globally human health and economy. Research in progress has shown facts associated with this disease and raised questions relevant for disease control and prevention. In this perspective, the collaboration between science and art in visual communication using the artwork "Enseñanza" ("Teaching") contributes to the representation of the lessons learned from COVID-19 and the way forward. To advance preparedness for current and future pandemics, the authors propose to address international collaborations, support to science, access to food supplies and health services, sustainable development and a "One Health" approach searching a balanced interaction of humanity with nature and a more holistic approach to disease prevention and control.
\end{abstract}

\section{Keywords}

Coronavirus, COVID-19, communication, art, pandemic

\section{Introduction}

The society's capacity for development is based on the ability to manage resources that have evolved from nomadic hunting to agriculture and animal domestication to industrialization and global commerce. These processes have increased human-to-human interactions and destruction of ecosystems, which have been accompanied by epidemiological transitions driven by epidemics such as the recent coronavirus disease 19 (COVID-19) caused by severe acute respiratory syndrome coronavirus 2 (SARS-CoV-2) [1, 2]. This pandemic has affected millions of people worldwide with a strong impact on human health and global economy. Additionally, measures in response to COVID-19 may affect animal health through reduction in disease prevention and control interventions [3]. 


\section{Facts and questions}

Although the exact origin of the SARS-CoV-2 has not been demonstrated, it probably came from insectivorous bats through other likely carnivorous unknown intermediate animal hosts to humans [2]. Current human behavior with more international traveling and contacts between different populations and animal translocations, facilitates virus crossing over from bats to humans and dissemination worldwide. Could a more balanced human-nature relationship have avoided pathogen emergence or mitigated disease impact?

These facts also raised a number of scientific questions that need to be addressed in order to better understand the origin and evolution of COVID-19. These questions include among others (a) SARS-CoV-2 origin, virus animal hosts, and zoonotic transmission, (b) risks of reverse-zoonotic human-to-animal virus transmission and establishment of new animal reservoirs, (c) virus evolution and pathogenicity, (d) molecular host-virus interactions, (e) immune response to infection and disease symptomatology, (f) role of the microbiota in disease prevention, evolution, and control, (g) epidemiology and environmental factors, (h) factors driving reduction in disease severity, and (i) virus maintenance in the environment $[4,5]$.

\section{Advancing preparedness for current and future pandemics}

The collaboration between science and arthas advanced addressing scientific questions and the communication of research challenges and results to the society [6-9]. Visual communication is the transmission of knowledge using visual messages that effectively create meaning. Herein, to advance preparedness for COVID-19 and future pandemics, we used the piece "Enseñanza" ("Teaching") to provide a message of what we consider is important to achieve this goal (Figure 1).

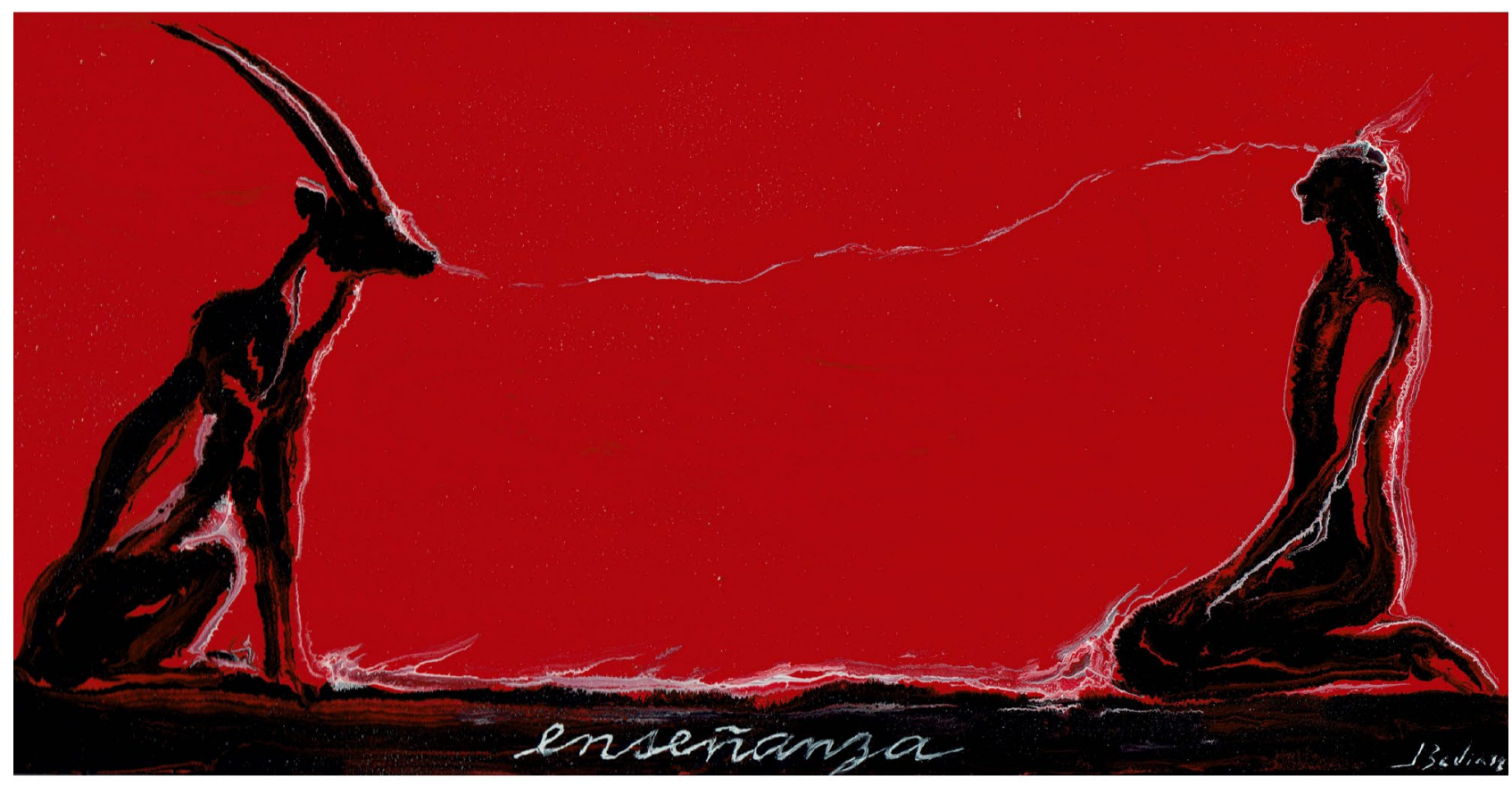

Figure 1. "Enseñanza” (“Teaching”). José Bedia, 2018, enamel on wood, $15 \mathrm{~cm}$ x $30 \mathrm{~cm}$. Courtesy KGJ Collection, Spain

According to the artist, the piece represents the relationship between humans and nature, which is the basis of epidemiological transitions, through an image of a human and animal that is recurrent in his work. The representation is linear and simple, the line of the horizon and two figures on the extremes with profiles of a human and animal (gazelle). The piece represents a transcendental and timeless meeting between a human (representing culture) and an animal (representing nature even if the body has been humanized) with the accompanying text "enseñanza" (meaning teaching in Spanish) to illustrate a teacher-student relationship without clarifying who is who. It shows a regular distance with silent learning and communication. This representation is influenced by Mayan painted ceramic vases from the classical period. In the ceramic the 
idea evolves circularly in the cylinder of the vase, but herein it appears as an illustrated strip. In the artist's pieces, the figures are usually static and always in a seated and reflective position.

Interventions for the control of current COVID-19 pandemic include diagnostic [reverse transcriptionpolymerase chain reaction (RT-PCR), serology, environmental monitoring], epidemiological studies with case mapping, contact tracing, vaccines, care of social distance, palliative treatments, and personalized medicine including the use of prebiotics/probiotics. Pathogen-specific vaccines will contribute to the control of COVID-19 as shown for other diseases [10]. However, interventions boosting the immune response with a broader and not pathogen-specific immunity may contribute not only to the control of COVID-19 but also to other pathogens that may cause future pandemics [11].

However, as represented in Figure 1 through the interaction and learning process between humans and nature, lessons learned from COVID-19 would advance preparedness for current and future pandemics. These advances should focus on international collaborations, support to science and scientists to address questions posed by this pandemic, guarantee access to food supplies and health services to the whole population, sustainable development and a "One Health" approach searching a balanced interaction of humanity with nature and a more holistic approach to disease prevention and control.

\section{Abbreviations}

COVID-19: coronavirus disease 19

SARS-CoV-2: severe acute respiratory syndrome coronavirus 2

\section{Declarations}

\section{Acknowledgments}

The authors acknowledge the contributions of SaBio group members and collaborators to the study of COVID-19.

\section{Author contributions}

JF and CG contributed conception of the paper; JB contributed the art piece; JF wrote the first draft of the manuscript. All authors contributed to manuscript revision, read and approved the submitted version.

\section{Conflicts of interest}

The authors declare that they have no conflicts of interest.

\section{Ethical approval}

Not applicable.

\section{Consent to participate}

Not applicable.

\section{Consent to publication}

Not applicable.

Availability of data and materials

Not applicable.

\section{Funding}

Not applicable.

\section{Copyright}

(C) The Author(s) 2020. 


\section{References}

1. Armelagos GJ. The viral superhighway. The Sciences. 1998;38:24-9.

2. Zhou P, Yang XL, Wang XG, Hu B, Zhang L, Zhang W, et al. A pneumonia outbreak associated with a new coronavirus of probable bat origin. Nature. 2020;579:270-3.

3. Gortázar C, de la Fuente J. COVID-19 is likely to impact animal health. Prev Vet Med. 2020;180:105030.

4. Riggioni C, Comberiati P, Giovannini M, Agache I, Akdis M, Alves-Correia M, et al. A compendium answering 150 questions on COVID-19 and SARS-CoV-2. Allergy. 2020;[Epub ahead of print].

5. Fernández de Mera IG, Rodríguez del Río FJ, de la Fuente J, Pérez Sancho M, Hervás D, Moreno I, et al. COVID-19 in a rural community: outbreak dynamics, contact tracing and environmental RNA. Preprints [Preprint]. 2020 [cited 2020 Jul 12]. Available from: https://www.preprints.org/ manuscript/202005.0450/v1

6. Eldred SM. Art-science collaborations: change of perspective. Nature. 2016;537:125-6.

7. Artigas-Jerónimo S, Comín JJP, Villar M, Contreras M, Alberdi P, Viera IL, et al. A novel combined scientific and artistic approach for the advanced characterization of interactomes: the Akirin/Subolesin model. Vaccines (Basel). 2020;8:77.

8. de la Fuente J. The exquisite corpse for the advance of science. Arts sci. 2020;4:1-10.

9. de la Fuente J, Estrada-Peña A, Cabezas-Cruz A, Brey R. Flying ticks: anciently evolved associations that constitute a risk of infectious disease spread. Parasit Vectors. 2015;8:538.

10. Cohen J. Vaccine designers take first shots at COVID-19. Science. 2020;368:14-6.

11. Cabezas-Cruz A, de la Fuente J. Immunity to $\alpha$-Gal: toward a single-antigen pan-vaccine to control major infectious diseases. ACS Cent Sci. 2017;3:1140-2. 